\title{
Asef Bayat
}

\section{ACTIVISM AND SOCIAL DEVELOPMENT IN THE MIDDLE EAST}

This article is about social activism and its relationship to social development in the Middle East. It examines the myriad strategies that the region's urban grass-roots pursue to defend their rights and improve their lives in this neo-liberal age. Prior to the advent of the political-economic restructuring of the 1980s, most Middle Eastern countries were largely dominated by either nationalist-populist regimes (such as Egypt, Syria, Iraq, Libya, Sudan, Turkey) or pro-Western rentier states (Iran, Arab Gulf states). Financed by oil or remittances, these largely authoritarian states pursued state-led development strategies, attaining remarkable ( $21 \%$ average annual) growth rates.' Income from oil offered the rentier states the possibility of providing social services to many of their citizens, and the ideologically driven populist states dispensed significant benefits in education, health, employment, housing, and the like. ${ }^{2}$ For these post-colonial regimes, such provision of social welfare was necessary to build popularity among the peasants, workers, and middle strata at a time that these states were struggling against both the colonial powers and old internal ruling classes. The state acted as the moving force of economic and social development on behalf of the populace.

The authoritarian nature of these states restricted meaningful political participation and the development of effective civil-society organizations. The regimes' etatist ideology and patrimonial tendencies rendered the states the main, if not the sole, provider of livelihoods for many citizens, in exchange for their loyalty. In etatist models, the state controls the bulk of the economic, political, and social domains, leaving little space for society to develop itself and for interest groups to surface, compete, and act autonomously. In the Middle East, such ideology often led to the demobilization-or, at best, controlled mobilization - of certain segments of the population, as exemplified by the corporatist unions under Gamal Abdel Nasser and currently in Syria; the state-run syndicates under the Shah of Iran; the Islamic Associations under Ayatollah Khomeini; and the People's Councils in Libya.

The advent of "liberalization" and marketization through the International Monetary Fund-sponsored Economic Reform and Structural Adjustment programs (ERSA) has 
provoked important socio-economic changes. Free-market economies have made consumer commodities vastly more accessible and enriched the upper socio-economic strata while also increasing income disparities and causing critical changes in labor markets. Informal and marginalized groups, such as the unemployed, casual workers, and street subsistence laborers, have expanded. A large number of public-sector workers and rural laborers, as well as educated, once well-to-do members of the middle class (government employees and college students), have been pushed into the ranks of the urban poor in labor and housing markets.

In the meantime, states have gradually been retreating from the social responsibilities that characterized their early populist development. Many social provisions have been withdrawn, and the low-income groups largely have to rely on themselves to survive. For instance, in Egypt, state subsidies on certain basic foodstuffs such as rice, sugar, and cooking oil have been removed, and subsidies on items such as fuel, power, and transportation have been reduced. Rent control is being reconsidered; a new land law has ended tenant farmers' control over land; and pubic-sector reform and privatization continue, all with significant social costs. From as early as 1993, a United States Agency for International Development report was warning of the "deteriorating social conditions in Egypt." Although certain social indicators such as life expectancy and infant mortality have improved, unemployment, poverty, and income gaps reportedly increased in the 1990s. ${ }^{5}$ Similar changes are taking place in Jordan, resulting from a series of events such as the second Gulf War, which deepened the crisis there. ${ }^{6}$ In Iran, the government has been vacillating between etatism and free-market policies since 1990. Compared with that in other countries in the region, the direction of economic liberalization in Iran has been slow, due partly to labor resistance and partly to the struggle among political factions. Although the Syrian economy remains predominantly under state control, the private sector is being allowed to expand gradually.

Concurrent with these political-economic developments have been the globalization of the ideas of human rights and political participation, which have placed economic rights and citizen participation on the political agenda and subsequently helped to open new spaces for social mobilization. The inability of populist states to incorporate or suppress the new social forces (such as lower-middle and middle classes) that they have helped to generate has led to the growth of civil-society institutions. When states are unable to meet the needs of these classes, they resort to (and encourage the establishment of ) civil associations to fulfill them. ${ }^{8}$ Recent surveys on civil society in the Middle East suggest that, despite the authoritarian nature of many states, humanrights activists, artists, writers, religious figures, and professional groups have brought pressure to bear on the governments for accountability and openness.?

These overall economic and social changes - notably, the deteriorating social conditions of the poor, on the one hand, and the expansion of the public sphere and civil institutions, on the other-raise some crucial questions. How do the grass-roots in the Middle East react to their changing social and economic realities? And if they indeed confront their changing circumstance, what is the logic behind the shift in the nature of demands, sites of protests, and patterns of activism in the region? To what extent is "pressure from below" required for meaningful policy change and institutional reform conducive to social development for defending people's livelihoods and rights in the Middle East? By addressing such questions, this article attempts to explore the 
nature of grass-roots activism in the region to defend livelihoods and pursue social development.

As a generic term, "activism" refers to any kind of human activity-individual or collective, institutional or informal-that aims to engender change in people's lives. As an antithesis of passivity, "activism" includes many types of activities, ranging from survival strategies and resistance to more sustained forms of collective action and social movements. ${ }^{10}$ My focus on the issue of activism is a reaction partly to the virtual absence of the people from the economic-development discourse, notably ERSA, and partly to the dearth of scholarly work on social movement and social development in the Middle East compared with Latin America and South Asia.

This is not to downplay some important recent works on the subject. Marsha Posusney, who is working on privatization and labor unions in Egypt; Unni Wikan, Diane Singerman, and Homa Hoodfar, who have studied Cairo's poor families; and Val Moghadam and Haleh Afshar, studying women and development have made valuable contributions. " However, the grass-roots activities described by most authors remain broadly in the realm of survival strategies-activities that are carried out often at the cost of the actors' themselves or fellow humans. For instance, cutting down on one's consumption or working in multiple jobs may ensure survival but at the cost of possible malnutrition or exhaustion.

This article shows that grass-roots activism in the Middle East is much more complex, diverse, and dynamic. I discuss six types of activism expressed in urban mass protests, trade unionism, community activism, social Islamism, nongovernmental organizations (NGOs), and quiet encroachment. I argue that past collective or mass urban protests and labor unionism failed to improve the living conditions of a large number of people. Community activism has been feeble. And social Islam and NGOs address only some of the problems. Middle Eastern societies thus foster quiet encroachment as a viable strategy that gives the urban grass-roots some power over their own lives and influence over state policy. Quiet encroachment is characterized by direct actions of individuals and families to acquire the basic necessities of their lives (land for shelter, urban collective consumption, informal jobs, business opportunities) in a quiet and unassuming, illegal fashion. These prolonged and largely atomized struggles bring about significant social changes for the actors.

I conclude by highlighting a number of tendencies in the form and location of grass-roots mobilization in the region. I point to notable shifts from class-based organizations (trade unions, peasant organizations, and cooperatives) to more fragmented activities positioned in the informal sector, NGOs, and social Islam; from campaigns for monetary entitlements to struggles for citizenship; and from the expression of demands in the workplace to their expression in communities. Because of rapid urbanization, cities increasingly have become sites of conflict and struggle, ${ }^{12}$ and national struggles are increasingly assuming urban expression. Therefore, whereas numerous movements-notably, those associated with human rights, democracy, women, and farmers - deal with some aspects of social development, this article focuses on the social activism of the urban grass-roots, an issue that is frequently overlooked. Although I have attempted, at the risk of overgeneralization, to survey many countries in the Middle East, much of the data comes from Iran and Egypt because of their rich and varied experiences of social mobilization. 


\section{Asef Bayat}

URBAN MASS PROTESTS

The urban riots of the 1980s were an early expression of discontent with some aspects of neo-liberal policies in the Middle East, as various countries tried to reduce their deficits through austerity policies, such as cuts in consumer subsidies. These reductions violated the social contract between the states and the masses, triggering anger and discontent. Although it is difficult to determine the precise profile of the participants, the urban middle and lower classes were among the main actors. In August 1983, the Moroccan government reduced consumer subsidies by 20 percent. Even though public-sector salaries were raised by an equal amount, riots broke out in northern Morocco and other regions. Similar riots occurred in Tunis in 1984 (89 killed) and in Khartoum in 1982 and 1985 (number of dead unknown). In the summer of 1987, Lebanese involved in the civil war got together to stage a massive demonstration in Beirut against the drop in the value of the Lebanese pound. Algeria was struck by cost-of-living riots in the fall of 1988, and Jordan experienced similar violence in 1989. ${ }^{13}$ This list excludes many political protests that raised issues concerning individual freedoms, regional autonomy, and professional matters (e.g., at Egypt's Military Academy in 1986 and in the Iranian cities of Tabriz and Qazvin and, more recently, among students in 1999).

Despite the acceleration of neo-liberal policies, urban mass protests ebbed noticeably during the 1990s. Several factors played a part. Alarmed by the earlier unrest, governments imposed tighter controls while delaying or implementing unpopular policies only gradually. Aside from internationally sponsored safety nets, such as the Social Fund for Development as in Egypt and Jordan, additional outlets were offered by the growth of welfare NGOs and social Islam.

The experience of the Islamic Revolution and the war with Iraq distinguished Iran from its regional counterparts. While many regimes in the Middle East were shedding their populism during the 1980 s and 1990 s, Iran began to experience that only after the revolution. The Islamic regime's rhetoric in favor of the downtrodden (mustaźafin) contributed to the mobilization of the grass-roots. The war suppressed internal dissent; once it ended, a new opportunity for collective activities, such as urban mass protests, arose. Thus, unlike the relatively quiet 1980 s, six major protests took place in Tehran and other Iranian cities in the early 1990s. Riots in Tehran in August 1991 and in Shiraz and Arak in 1992 were carried out by squatters because of demolition of their shelters or forced evictions. Even more dramatic unrest took place in the city Mashad in 1992 and Tehran's Islamshahr community in 1995. In Mashad, the protests were triggered by the municipality's rejection of demands by city squatters to legalize their communities. This massive unrest, on which the army failed to clamp down, left more than one hundred buildings and stores destroyed, three hundred people arrested, and more than a dozen people dead. The three-day riots in Islamshahr, a large informal community in South Tehran, in April 1995 had to do with the postwar economic austerity - notably, increases in bus fare and the price of fuel-under President $\mathrm{Ha}$ shemi Rafsanjani.

Urban protests in the Middle East have had mixed results. Following immediate repression, governments in many cases have had to revoke unpopular measures (as in Egypt in 1977, Tunisia and Morocco in 1984, Sudan in 1985, Algeria in 1988, Jordan 
in 1989, and Iran on many occasions). At times, they have made tactical concessions, such as increasing wages; this, however, affects only wage-earners at the expense of the self-employed poor and the unemployed. ${ }^{14}$ Where the protests are local or smallscale, the governments usually have managed to end them by force. Workers in Kafr al-Dawwar in Egypt managed to fulfill only part of their demands. The Egyptian farmers' protests in 1998 across isolated villages failed to modify the new policy that ended tenant farmers' long-term control over land. However, when social protests have gained national support by embracing diverse issues and actors (such as students and the middle classes making economic as well as political claims), they often provoke significant changes, including political reform (as in Algeria, Jordan, Tunisia, and Turkey in the late 1980s).

Despite their drama and, at times, their remarkable impact, urban mass protests are usually spontaneous, ad hoc, and consequently uncommon; they often involve violence and a risk of repression. Urban riots are a response to the absence of effective institutionalized mechanisms of conflict resolution. The social groups without institutionally based power to disrupt (such as the unemployed, who cannot strike) and those who enjoy such power but find it inadequate (workers, students) are likely to follow leaders in initiating mass protests. This is not to say, as some have claimed, that Middle Eastern masses essentially lack a "truly collective life," resorting instead to "mob action." ${ }^{15}$ For in favorable conditions, they also engage in modern forms of collective action-notably, trade unionism.

\section{TRADE UNIONISM}

Trade unionism represents an older and sustained institution through which working people have defended their rights or exerted pressure on economic elites and governments to bring about social change. Trade unions have the potential to respond rapidly and systematically to unjust labor practices, distributive issues, and political matters. At the same time, they are most affected by the current neo-liberal economic policies, which often result in new labor discipline and redundancies.

Originally, trade unions in the Middle East emerged in the context of European colonial domination. Their struggles, therefore, involved both class and nationalist dimensions - usually a tense strategic position. At independence, most trade-union organizations were integrated into the state structure or the ruling parties, resulting in the current situation, in which unitary, compulsory unions make up the majority of labor organizations. This type of union, in which public-sector workers constitute the core members, operates in countries with populist pasts (such as Algeria, Egypt, Iraq, Libya, and Syria) as well as in Kuwait and Yemen. The Arab Gulf states, using mostly foreign workers, impose tough discipline and disallow labor organizations in exchange for relatively high pay. Surveillance, however, has not prevented occasional outbreaks of labor unrest, such as the Palestinian workers' strike in the Saudi oil industry in 1980 s and the riots of Egyptian workers in Kuwait against discrimination in October 1999. ${ }^{16}$ Only Jordan, Lebanon, Morocco, and Turkey have pluralist unions that are relatively independent from the state or ruling parties.

Union structure affects workers' ability to maintain their gains or advance them. Independent unions, more than corporatist ones, are likely to defend workers' rights. 


\section{Asef Bayat}

However, in the experience of the region, workers tend to use the existing, corporatist organizations to further their own interests, as is shown in the state-controlled Workers Syndicates before the Iranian Revolution and Workers' Shuras and the Union of Unemployed Workers after. ${ }^{17}$ This applies also to the corporatist trade unions in Egypt established by Nasser following the liberal era (1928-52), when labor unions enjoyed a period of relative independence. ${ }^{18}$

Currently, organized public-sector workers, more than any other group, feel the immediate consequences of economic adjustment. Thus, trade unions are concerned with and often struggle against cuts in consumer subsidies, price rises, reductions in wages and allowances, layoffs, and government interference in union affairs. A human-rights organization reported seventy strikes against large companies in Egypt during 1998, most of which involved state security forces. The main cause of the industrial actions was "government reform policy."19 The Egyptian press, citing official statements, reported in early 1999 the occurrence of more than five strikes and sit-ins per week. These actions resulted largely from reductions in allowances and perquisites and the introduction of fines. ${ }^{20}$ In Iran, the 1990 s saw a rapid increase in worker strikes. During the first half of 1991, some 2,000 strikes were reported. ${ }^{21}$ According to one account, strikes by workers trying to catch up with inflation were so common that the authorities hardly noticed them. ${ }^{22}$ New labor laws, redrafted to accord with the neo-liberal era and economic realities, have been hotly contested, because they often strip workers of several traditional rights - notably, job security. In Egypt, the labor unions compelled government and business to accept in 1994 an exchange of "the right to strike for the right to fire." ${ }^{23}$ In Iran, labor law remained a matter of dispute between the ruling clergy and pro-labor forces for more than a decade.

Some observers tend to underestimate the capacity of organized labor in the Middle East to affect social and political developments on the grounds that strikes, the workers' major weapon, are illegal and often involve the risk of arrest and imprisonment. In addition, they argue, states usually co-opt the leaderships of these largely corporatist labor unions, thus rendering union activism practically ineffective. ${ }^{24}$ It is true that strikes are illegal, and labor leaders may be bought off, with many of them becoming part of the ruling parties and the state bureaucracy. However, Posusney rightly argues that "labor has been able to pursue economic demands and wring concessions from the state, in spite of corporatist controls," and its ability to do so "is contingent on the specific issue at hand and how policy around that issue is made." 25 The fact is that even the corporatist leadership must be somehow responsive to the views and concerns of its rank and file. Not only do labor leaders often express opposition to certain government policies (e.g., removal of subsidies, privatization, aspects of labor law), but the rank and file tend to wage unofficial industrial action when the leadership fails to take the initiative. In Egypt, for instance, opposition by organized labor has been the main cause of delays in the implementation or renegotiation of terms of adjustment with the IMF both currently and under previous government. ${ }^{26}$

Notwithstanding its social and political impact, organized labor in the Middle East has continued to comprise only a small portion of the total workforce. The vast majority have been self-employed, with a large fraction of wage-earners working in small workshops in which paternalistic labor relations prevail. Although tension between 
bosses and employees is not uncommon in these establishments, laborers are more likely to remain loyal to their bosses than to ally with their colleagues in the shop next door. On the whole, between one-third and one-half of the workforce in the cities (Egypt, 43\%; Iran, 35\%; Turkey, 36\%; Yemen Arab Republic, 70\%) are active in the informal sector, and thus remain unorganized and beyond the provisions of labor law. ${ }^{27}$

The economic restructuring of the 1980s has further undermined organized labor, as the public sector, the core of trade unionism, is shrinking because of closures, downsizing, and early retirements. Numerous reports point to the declining capacity of the region's labor movements to mobilize. Organized labor in Egypt, Lebanon, Morocco, Tunisia, and Iran is described as "disjointed," "defensive," "decapitated and de-proletarianized." ${ }^{28}$ Labor is becoming more informal and fragmented, with less or no protection, and dispersed across vast arrays of activities and spaces among the unemployed, casual workers, and domestic labor, in the small workshops, and on street corners. ${ }^{29}$

\section{COMMUNITY ACTIVISM}

For the urban grass-roots, then, urban community or neighborhood may offer a sense of common identity and a ground for collective action in the stead of the workplace. For in the neighborhoods, most face the same difficulties in ensuring secure housing, paying rent, and acquiring access to urban amenities, schools, clinics, cultural centers, and the like. Community-based collective struggles for such "collective consumption" through institutional settings is what in a sense characterizes the urban social movements. This kind of community activism, often contentious, should be distinguished from the notion of "community development." The latter has had a double effect of both maintaining the status quo and engendering social change. Indeed, the program of community development in the West was originally aimed at counter-insurgency against communism (in the colonies), containment of discontent among the black underclass (in the United States), and management of the poor by providing community solutions (in the United Kingdom). ${ }^{39}$ Yet community development may also open space to cultivate resistance against the elites and foster social change. This is often the case when the grass-roots initiate development on their own or are mobilized by local leaders, NGOs, religious groups, or politicians (as in Brazilian barrios or SelfEmployed Women's Association in India). Here mobilization may not necessarily be contentious; it could express cooperative community engagement whereby people work together to improve their lives and communities with a degree of control over decisions and their outcome. How do the Middle Eastern cities fare in terms of such community activism?

In recent years, a number of community mobilizations took place in Middle Eastern cities that bore some resemblance to urban social movements. Take, for instance, the campaign of the people of Ezbat Mekawy, a low-income community in Cairo, against industrial pollution in the area where smelters had caused major health and environmental problems. ${ }^{31}$ They used traditional strategies of communication within the community, as well as modern tactics such as engaging the media, lobbying politicians, and resorting to the court system as a means of registering opposition. In a different example, members of the Shubra al-Khaima community in Egypt rapidly responded 
to a governorate's plan in August 1994 to demolish an unauthorized section of a community complex (a mosque, a clinic, and a pharmacy) that had taken inhabitants ten years to build with their own money. ${ }^{32}$

At certain periods - notably, when states become more vulnerable-even more enduring and large-scale mobilization develops. The collapse of the state during the Lebanese civil war caused community mobilization in the Muslim south, where its institutions continue to this day. Thousands from the south moved to the southern suburb (dahiya) of Beirut, building illegal settlements that currently make up 40 percent of the homes in the area. Following the Iraqi invasion of Kuwait in August 1990, networks of volunteer and associational groups played a vital role not only in supporting civil disobedience, but also in filling the vacuum created by loss of municipal services. ${ }^{33}$ The Palestinian Popular Organizations acted as the main organs of social provisioning and development in the Occupied Territories both during the Intifada and after. ${ }^{34}$ Immediately after the Iranian Revolution of 1979, many poor families took over hundreds of vacant homes and half-finished apartment blocks, refurbishing them as their own properties and establishing apartment councils to manage them collectively. In the meantime, land takeovers and illegal construction accelerated. With the help of local and outside mobilizers, squatters got together and demanded electricity and running water; when they were refused or encountered delays, they acquired them illegally. They established roads, opened clinics and stores, constructed mosques and libraries, and organized refuse collection. They further set up associations and community networks and participated in local consumer cooperatives. A new and a more autonomous way of living, functioning, and organizing community was in the making.

However, when compared with some Latin American countries, these experiences seem acutely uncommon. They tend to happen in extraordinary social and political circumstances - in revolutionary conditions or in times of crisis and war, when the state is undermined or totally absent, as in Palestine. Thus, few such activities become a pattern for sustained social mobilization and institutionalization in normal situations. Once the exceptional conditions come to an end, the experiments begin to wither away or get distorted. In Iran, community activism did not get a chance to consolidate itself. Lack of experience, rivalry of outside mobilizers and political groups, and especially the hostility of the government seriously undermined the experiment. Instead, Mosque Associations were established not only to offer the locals assistance in distributing basic necessities such as food during the war with Iraq; they served also to control political discontent in the neighborhoods. They resembled the 3,000 Community Development Associations (CDAs) that currently operate throughout Egypt. ${ }^{35} \mathrm{Al}-$ though CDAs contribute to the poor's social well-being, their mobilizing impact is minimal. As a field researcher working in a popular quarter of Cairo stated: "Even in the highly politicized Sayyeda Zeinab, organized social action that involves the area's inhabitants seems minimal. The residents' role is usually limited to that of beneficiaries of whatever services ... are available. ${ }^{" 36}$

Needless to say, urban communities are not blank spots devoid of social interaction. Surely, they are more than small villages subject to individualism, anonymity, and competition. Nevertheless, they contain numerous forms of networks and institutions. In the modern city of Tehran, neighborly relations, according to a recent study, still prevail; members participate in assisting one another, pay visits, consult, and take part 
in weddings and funerals. ${ }^{37}$ In Egyptian cities, Migrant Associations have institutionalized some of these functions; funeral activities and maintaining cemeteries for the people from "home villages" are their main activity. ${ }^{38}$ Influential individuals may take advantage of the state-controlled neighborhood councils (majälis al-mahalliyyah, shürā-yi mahallāt). But the informal credit systems (such as the jama'iyat in Egypt and sanduq-i qarz al-hasanih in Iran) serve as perhaps the most important form of community network in urban centers.

Social networks that extend beyond kinship and ethnicity remain largely casual, unstructured, and paternalistic. The weakness of civic or non-kinship cooperation at the community level only reinforces traditional hierarchical and paternalistic relations with people depending on local leaders (kibār, shaykhs, Friday prayer leaders), problem-solvers, and even local bullies (lāts or baltajiyya) rather than on broad-based social activism. In such social conditions, the modern institutions such as politicalparty branches, local NGOs, or police are susceptible to clientism. Thus, while the Egyptian lower classes, for instance, are aware of environmental problems, they undertake little in the way of collective action, either through communal engagement to upgrade the community itself or through protest actions to demand that officials do this for them. ${ }^{39}$

Why is community activism, a social action for collective consumption, relatively uncommon in the Middle East? Why is the region a "blank space" in the global map of community action, as some observers have put it? ? $^{40}$

One reason has to do with the legacy of populism, which continues to influence the political behavior of the ordinary people in most Middle Eastern countries. Populist regimes established a social contract between the lower and middle classes and the state, whereby the state agreed to provide the basic necessities in exchange for their support, social peace, and consequently demobilization, or just a controlled mobilization. This was not an agreement between the state and independent classes. Rather, it was an agreement between the state and a shapeless mass, an aggregate of individuals and corporate institutions in which independent collective identity and action were seriously undermined. Although distributive populism is currently waning and market forces are escalating, many people still tend to look at the states as the main source of protection as well as misfortune. In countries where authoritarian populism still predominates (such as Iran in the 1980s, Libya, and Syria), the statesmen's dread of the public sphere has given a structure to the regimes that in some ways incarcerate the entire population.

This legacy has also contributed to the tendency among many ordinary people to seek individualistic solutions to their problems. ${ }^{41}$ More often than not, families of different social strata tend to compete when resources are scarce. This occurs even more often in the new and heterogeneous communities (such as Dar Essalaam, Madinat al-Nahda, and Kafr Seif in Cairo, and Islamshahr and Khak-i Safid in Tehran) than in the old city quarters, where the relative homogeneity of inhabitants and the longevity of residence have produced a spatial identity. The coexistence of identifiable strata in a community - such as old-timers and newcomers, those with and without security of tenure, and different ethnic groups - often sharpens the existing competition, leading to conflicts. ${ }^{42}$ Consequently, with solidarity intangible among the people, recourse to the mighty state-this provider and punisher-becomes an alternative 
way to achieve their goals. Many of them know, however, that the bureaucracy is unable or unwilling to respond formally to the growing demands of the urban poor, and they tend to seek informal, individualistic, and even opportunistic ways to cultivate wasta or parti (connection) or bribe the officials. "The best way to get whatever you want done," said a resident of the Sayyida Zeinab district of Cairo, "is to pay a bribe to any of the assistants of any of the area's big politicians and they will do for you whatever you want."

A key contributor to such social response is the lack of a structure of opportunity for mobilization. The advent of neo-liberal economies in the Middle East has not accompanied a sufficiently democratic polity. ${ }^{44}$ Put simply, most governments in the region are still apprehensive of and tend to restrict independent collective mobilization for fear of losing political space. In many states, public demonstrations and gatherings are largely illegal. As a street vendor in Cairo's Madinat al-Nahda invoking Egypt's Emergency Law said: "If I call my neighboring street vendor to get together and do something collectively, this would be called mobilization, and I could be taken in for that." ${ }^{45}$ A human-rights agency's account of farmers' protests in twenty-five villages against the new land law in Egypt in the course of eight months reported fifteen deaths, 218 injuries, and 822 arrests. $^{46}$

Alternatively, the governments may allow popular initiative in order to control it. Where it succeeds in doing so, the popular classes tend to lose interest, with the result that their activism fails to sustain itself. Because the supporting environment is lacking, they fail to experiment and learn new ways of doing things. Thus, most of the genuine popular institutions transform into the extension of the states.

Political democracy is instrumental in another way. In a truly competitive polity, political forces are compelled to bargain with and thus mobilize the grass-roots to win their electoral support. This is how the urban poor in Iran became the subject of an intense competition between the ruling clergy and various oppositional groups in the early 1980s. Similarly, a sustained competitive system in Turkey allowed the Islamist Rifah Party (RP) to mobilize the urban masses in the twenty-six municipalities it controlled, thereby giving the electorate strong bargaining power. Manipulative electoral practices in Egypt, however, tend to limit the oppositional parties to restricted local campaigns, as in Ezbet Mikawy described earlier.

Finally, collective patronage may also lead unintentionally to social and political mobilization when patrons bargain with their poor clients' leaders in their quest for personal and political power. Mobilization of street vendors in Mexico City through negotiation between the vendors' union leaders and politicians is partly the result of this type of political patronage. ${ }^{47}$ In much of the Middle East (except in Lebanon and in the case of Istanbul's street car-parkers' "mafia"), however, patronage seems to work more through individual channels and rarely leads to group activities. Favors are granted to individuals or families (in getting the security of tenure or jobs, for instance) than groups who then can bargain with their patron in exchange for his support.

In brief, community activism in the form of urban social movements seems to be largely a Latin American model rooted in socio-political conditions of that region (although it can be found in South Africa and, to a lesser extent, in India). The likes of local soup kitchens, neighborhood associations, church groups, and street trade 
unionism are hardly common features in the Middle East. The prevalence of authoritarian states and the legacy of populism, together with the strength of family and kinship ties in this region, render primary solidarities more pertinent than secondary associations and social movements.

\section{ISLAMIST MOVEMENTS AND SOCIAL DEVELOPMENT}

Some observers view the current Islamist movements in the region as the Middle Eastern model of urban social movements. In this vision, Islamism-in particular, "social Islam"- articulates the concerns and struggles of the underprivileged urban Middle Easterners. For many, the seemingly disadvantaged background of the radical Islamists is indicative of the nature of the movements. Others look at the locations of their activities, in poor areas, to arrive at similar conclusion. ${ }^{48}$

No doubt, Islamist movements - notably, "social Islam"-represent a significant means through which some disadvantaged groups survive hardship or better their lives. The Islamist movements contribute to social welfare first by directly providing services such as health care, education, and financial aid; at the same time, they offer involvement in community development and a social network, most of which are carried out through local, nongovernmental, mosques. Second, the Islamist movements tend to foster social competition wherein other religious and secular organizations are compelled to become involved in community work. Finally, the governments, in order to outmaneuver the Islamists and regain legitimacy, are often forced to implement social policies in favor of the poor.

Although Islamic social-welfare has a long history in the Middle East, it has multiplied and taken on new forms in recent decades. During the recent growth of Islamism in Turkey in the 1980s, "mosques and their attendant religious associations represented direct channels of neighborhood organization and recruitment." ${ }^{, 49}$ The Islamist RP continued in the 1990s to focus on grass-roots community issues- "garbage, potholes and mud." Many RP mayoral candidates even distributed in-kind incentives to secure support. This grass-roots strategy led to the party's massive victory in the 1994 elections, capturing 327 municipalities throughout Turkey, including Ankara and Istanbul. Mayors have boasted in successfully addressing the problems of congested transportation, water and fuel shortage, inadequate housing, pollution, corruption, and the like. ${ }^{50}$ Similarly, the Islamic Salvation Front (FIS), a coalition of different Islamist parties in Algeria, prevailed in municipal elections in June 1990 in a very similar fashion. When the National Liberation Front allowed multiparty system in 1989, FIS activists began to work within the existing Charity Associations (mosque-centered networks) that had been established in the 1980 s by religious activists. Supported by the Charity Associations, the FIS took its political ideas into the neighborhoods. ${ }^{51}$

In a quite different context, Hizbullah filled the vacuum created by the absence of the state in southern Lebanon to construct the infrastructure for social development. During the 1980 s, Hizbullah began gradually to address social problems faced by the Shi i community. It developed plans to offer medical care, hospital treatment, electricity, and water trucking. It also paved roads, built housing, managed sewage systems, set up gas stations, and operated schools, nurseries, hospitals, and sports centers. ${ }^{52}$ It provided 130,000 scholarships, aid for 135,000 needy families, and interest-free loans. 
Repairing war-damaged houses and attending to daily needs of the population in areas of Shic i concentration were priority areas of intervention. ${ }^{53}$

Egypt's social Islam has become perhaps the most pervasive phenomenon in the region. The Islamic associations, often centered in ahli mosques (built and controlled by the people rather than the state) grew extensively in part because the government's development programs had fallen into crisis in the past two decades. They accounted for one-third of all Egyptian private voluntary organizations (PVOs) in the late 1980s, and at least 50 percent of all welfare associations (or 6,327) in the late $1990 \mathrm{~s},{ }^{54}$ offering charity and health services to millions. Today, more than 4,000 Zakat (religious tax) Committees organized in mosques mediate between the donors and the needy. Some estimates put the number of beneficiaries of the Islamic welfare (health) services at 15 million people (in 1992), as opposed to 4.5 million in $1980 .^{55}$ Indeed, the mosques came to provide alternative support services to low-income groups to compensate for the government's withdrawal of support after adopting more liberal economic policies. One typical association, the Ansar al-Muhammadiya Association in the poor community of Imbaba, built a mosque and two schools and provided day care, medical treatment and an elaborate welfare program. ${ }^{56}$ Others offered video clubs, computer-training centers, and similar services to cater to the needs of such groups as the high-school graduates who are the potential recruits of the radical political Islamists. Contrary to the common perception, radical Islamists such as al-Gamaa al-Islamiyya and al-Jihad, were far less involved in urban community work. As rural and urban guerrillas, their strategy centered on armed attacks, targeting the state officials, police, and tourism. Nevertheless, where possible, they combined their political agitation with some welfare activities, as they did in such poor quarters of Cairo as Ain al-Shams and Imbaba. ${ }^{57}$

What makes all of these activities "Islamic" is the combination of an alternative to both the state and the private sector, the religious conviction of many of their activists, Islamic-based funding, and, finally, the provision of affordable social services. It is widely agreed that such Islamic community activities often outdo their secular counterparts. The availability of funding in the form of zakat ( $2.5 \%$ of income) from Muslim businesses and activists, șadaqāt (various donations), khums (a fifth) levied on the savings of Shi i Muslims, and external aid (e.g., from Iran to Hezbollah and from Saudi Arabia to the FIS) render these associations comparatively advantageous. In the early 1990s, the Nasser Bank, which supervises the Zakat Committees in Egypt, reported a $\$ 10$ million zakat fund. ${ }^{58}$ The additional advantages include the spirit of voluntarism, as well as legal favor. That is, unlike secular NGOs, which have to surmount many bureaucratic hurdles to raise funds, the religious PVOs tend to get around the law by obtaining donations and other contributions from Muslim believers in places of worship. ${ }^{59}$

The grass-roots activities of the Islamists, in the meantime, compelled other social forces to enter into the competition hoping to share this political space. The Turkish țariqās (religious orders) emulated one another in community activities through mosques and their attendant associations. ${ }^{60} \mathrm{Al}$-Azhar, the pillar of establishment Islam in Egypt, began to offer similar social services to the needy in competition with the Muslim Brotherhood and al-Gama’a al-Islamiyya. Similarly, secular groups-notably, secular NGOs - seem to work hard to offer their own piecemeal alternatives. An esti- 
mated 5 million poor benefited from the health, educational, financial, and community services of Egyptian PVOs in $1990{ }^{61}$ In addition, the governments were affected, as they feared losing the political initiative to the Islamists. The Egyptian government's measures to upgrade slums and squatter areas in the early 1990 s clearly reflected the influence of Imbaba, the slum community in Cairo in which by 1992 militant Islamists had created, according to foreign media, "a state within the state."62

Given these activities, to what extent does Islamism represent a Middle Eastern model of urban social movements? To what degree does Islamism embody grass-roots activism in communities or work collectives? How far do the Islamists encourage the grass-roots to participate in their own affairs, to defend and extend their social rights? I suggest that although Islamism, notwithstanding its variations, may be considered a form of social movement, it does not express an urban social movement. The identity of Islamism does not derive from its particular concern for the urban disfranchised. It has never articulated a vision of an alternative urban order around which to mobilize the community members, whom the Islamists see as deserving welfare recipients, to be guided by leaders. The members are rarely expected to participate actively in making their communities.

The Islamist movements have more extensive aims than simply focusing on the disfranchised, although many activists work through the poor communities to pursue broader objectives. Not all, however, operate even in this fashion. For example, in Iran before the revolution, neither the clergy nor non-clerical Islamists, such as Ali Shariati, were particularly interested in mobilizing the poor; nor did the poor take an active part in the Islamic Revolution. The mobilization of the urban grass-roots by the ruling clergy in Iran began mainly after the revolution. The clergy lent its support to the poor through the rhetoric of the mustaziafin (downtrodden), first, to offset the stands in favor of the lower class taken by the left and the Mujaheddin, and second, to win over the poor as their social basis in their struggles against the left, liberals, and the remnants of ancien regime. The honeymoon between the poor and the ruling clergy was over when the poor were polarized. A segment was integrated into the state structure as members of the revolutionary institutions, such as Revolutionary Guards, Construction Crusade, and the like; others remained outside, and their struggles for development brought them into confrontation with the regime.

The Lebanese Hezbollah, with its law-enforcement apparatus, fell somewhere between a social movement and a quasi-state. Among other things, Hezbollah constructed an infrastructure of social development, but few of these services were free. ${ }^{63}$ Currently, the Hezbollah and Amal movements control the poor suburban municipalities of South Beirut. Although they use the United Nations Development Program discourse of participation and mobilization, their attitudes toward the local people remain paternalistic. They often select (not elect) people to municipality councils and cooperate with those NGOs which are closer to them. ${ }^{64}$ However, alongside their mobilization of the grass-roots, Turkey's RP and Algeria's FIS adopted exclusivist and divisive measures. The RP-dominated municipalities practiced nepotism and patronage, laid off secular employees in favor of religious ones, favored contractors who donated money to the party, and overlooked illegal real-estate construction in exchange for donations. The RP's policy of "cultural purification" tended to divide communities. ${ }^{65}$ Taking a similarly exclusionary stand, Egypt's al-Gama'a al-Islamiyya in 
Imbaba forced women to veil themselves, burned video shops and hairdressing salons, and beat men who drank alcohol. The Christian residents turned fearful and insecure.

While organized labor generally has remained out of the Islamists' reach, the relationship between the Islamists and the urban poor has been complex. For instance, contrary to common perception, Islamic social-welfare organizations in Egypt are not sites of Islamist political activity. They simply act as service organizations. The vast majority have no link to political Islam as such. Only a few were affiliated with the Muslim Brotherhood and a mere handful with the radical Islamists, notably al-Gama'a al-Islamiyya. The rest operate on the basis of humanitarian commitment or simple business rationale in a country where the market for "Islamic" commodities (Islamic fashion, books, education, and entertainment) has been thriving. The explicit political stance emerged in the welfare associations not in the poor areas, but in the middleclass neighborhoods and among professional associations of doctors, engineers, and lawyers who were allied with the Muslim Brotherhood. ${ }^{66}$ However, the spread of Islamic services and commodities is not restricted to the poor neighborhoods or exclusively to Muslims. It extends to middle-class and affluent districts and to the Christian community. The Islamic schools are not free of charge but private institutions that virtually exclude the poor. In the Imbaba slum, for instance, only a fraction were admitted free of charge. ${ }^{67}$ The Islamic schools are geared largely toward the well-todo, urban middle classes.

Although it has links to diverse classes, Islamism in the Middle East is primarily a movement not of the disfranchised but of the marginalized middle classes. Middleclass agitators in turn tend to activate the youth and the educated unemployed, as well as the socially well-to-do and politically marginalized groups. It is these groups that are considered the main agents of social change. Activities among the poor are largely limited to the provision of social services, often charity, and mobilization during elections in which free balloting takes place. In exchange, the Muslim poor in the cities approach the Islamists in pragmatic terms. Many of those who have no direct interaction with the Islamists remain confused as to their intentions. Others who benefit from their activities appear both appreciative and apprehensive. There is no evidence suggesting that the urban poor as a whole have offered an ideological allegiance to the Islamists or to the governments that have fought against the Islamists. Islamist movements, therefore, are distinct from Latin American Liberation Theology. The strategic objective of the Liberation Theology has been the "liberation of the poor"; the interpretation of Gospel follows from this point of departure. ${ }^{68}$ The Islamist movements, however, generally have broader social and political objectives (e.g., an Islamic state, law, and morality) than simply the mustażafin, and secular issues such as social justice for the poor follow only from the establishment of Islamic order-the most noble objective. ${ }^{69}$ In addition, what most Islamists share is a particular moral vision of society, which is repressive in terms of gender relations and intolerant of religious minorities and modern-secular forces with a stake in building a non-religious democratic polity. Ideological monopolies disrupt the process of pluralist democratization and frustrate the truly participatory culture that is essential for a sustained social development. But does the vision behind non-religious NGOs offer a more viable alternative for such development? 
The remarkable expansion of the Islamic welfare associations in the 1980s and 1990s is as much a reflection of the trend toward Islamization as of the explosive growth of NGOs in the Middle East in general. The notable gathering in Cairo in May 1997 of some 700 NGO delegates from almost all of the Arab countries to follow up their discussions during the 1994 International Conference on Population and Development marks the growing significance attached to this sector.

Associational life is not new in the Middle East. Many countries in the region have a long history of philanthropic activities. Early-19th-century associations were religious, drawing either on the Islamic notions of zakat and sadaqiāt or the Christian value of charity. They were followed in the early 20 th century by largely secular welfare and charitable associations, some of which were also used to cover anticolonial campaigns. Many of the welfare associations were run mainly by women of aristocratic families who, through work in such associations, aimed to play a role in the public sphere, a domain occupied almost exclusively by men. Although the legacy of such associational culture has continued to the present, the recent NGOs are of a different breed and follow a different logic.

There are currently some 15,000 registered NGOs in Egypt, double the number that existed in 1977. By comparison, Tunisia has 5,000 NGOs, of which 10 percent are charity-based. Lebanon's NGOs grew from 1,586 in 1990 to more than 3,500 by 1996, in a population of 3 million; Jordan's NGOs have increased from 112 in 1980 to 800 today. The Palestinian Indigenous Ahli Organizations (IAOs) increased from 1,000 (including 800 in the Occupied Territories and some 200 in Israel) in the early 1990s to 1,800 today. (A number of them were registered with either Israeli or Jordanian authorities. But perhaps the more important ones, known as "mass-based organizations" were largely unregistered.) With regard to Iran, some accounts put the number of NGOs as high as 15,000 . However, this is likely to be an exaggerated figure. During the 1980s, in the course of the war with Iraq, many informal people's associations were set up. Yet because of the predominance of populism and Iran's "closeddoor" policy, the country's record of development NGOs is insignificant when compared with that of other Middle Eastern countries. Many relief and welfare activities in Iran are carried out by governmental or governmental-nongovernmental organizations - notably, the Imam's Relief Committee, the Foundation of Martyrs, the Construction Crusade, the Housing Foundation, and the Volunteer Women's Community Health Workers' Organization. However, since the late 1990s, a new trend has arisen toward setting up professional, women's health, and environmental NGOs. The Network of Women's NGOs currently includes 58-100 organizations, for instance. The new thinking, in era of President Muhamad Khatami, is that the local councils should be turned into the locus of popular participation, while the NGOs, currently numbering about 2,500 , should be in charge of delivering services and charity. ${ }^{70}$

NGOs in the region fall into four general types in terms of their rationale or the impetus behind their activities. The religiously motivated associations are organized by mosques and Islamic figures or by churches and Christian institutions. They are inspired by religious obligations or religious-political factors. Classical welfare as- 
sociations, run mostly by upper-class families, have now incorporated some developmental functions, such as income-generation, training, and community upgrading. Professional NGOs are managed largely by upper-middle-class professionals and, at times, by development experts who are driven by their training and humanistic urge or simply by material self-interest. And, finally, there are a host of state-sponsored "NGOs," such as the Egyptian Community Development Associations and the Iranian Foundation of Dispossessed. These groups remain, in effect, an extension of the state. Put together, these NGOs are active in diverse fields of human rights, women's issues, welfare, culture, business, and development. Here I will focus on welfare and development NGOs that target disadvantaged groups.

Several factors have contributed to the spectacular growth of the NGOs. First, as elsewhere, there was a need in the region's poorer countries (such as Egypt, Jordan, and Tunisia) to fill the gap left by the states' inability and unwillingness to face the challenge of social development following the implementation of neo-liberal policies. Population growth and urban migration had already placed a heavy pressure on urban social services. Where a state was absent or defunct, as in Lebanon and Palestine, organized self-help filled the vacuum. The second factor is the flow of foreign funding resulting from new donor policies that extend aid largely to NGOs rather than to individual states. External funding not only encouraged the establishment of NGOs; it often influenced their activities. When there was money for human-rights activities, for example, human-rights organizations were established. Third, there seems to be a unique consensus along the political spectrum-among neo-liberals, the World Bank, governments, and liberal and radical opposition groups - in support of the NGOs. The conservatives want to shift the burden of social provisions from the state to individuals. For them, NGOs act as a safety net to offset the possibility of social unrest caused by the repercussions of neo-liberal policies. In the view of Prince Talal 'Abd al-'Aziz Al-Saud of Saudi Arabia, "NGOs are the central component of development." According to a prominent Arab NGO advocate, "NGOs have replaced class struggle and socialism." Middle Eastern liberals and the left also support the NGOs for their perceived role as agents of social change from below, contributing ultimately to development and democracy. Thus, for a Palestinian activist, "the most important role of NGOs in a future Palestinian self-authority is to accelerate the speed of change, to mobilize the rural population and to democratize the society."72 Because of their small size, efficiency, and commitment to the cause of the poor, NGOs are seen as true vehicles for grass-roots participation in development. Consequently, they serve as a bulwark against the creeping spread of Islamic fundamentalism by offering an alternative outlet to the Islamist agendas.

How effective are the development and welfare NGOs in facing the challenge of social development in the Middle East? Most studies confirm that the sector is "a vital component of the nations' social safety net and important provider of valued social services." ${ }^{73}$ In Iraq, Lebanon, Palestine, and Sudan, where the states have been absent, defunct, or in deep crisis, NGOs play a vital role in survival, emergency aid, and relief. According to the World Bank, Palestinian NGOs in 1994 accounted for 60 percent of primary health-care services and 50 percent of all secondary and tertiary health-care services; 100 percent of the programs for the disabled and preschool chil- 
dren; and a sizable portion of agricultural, housing, small business credit, and welfare services. ${ }^{74}$ In addition, given the growing privatization and high costs of health care and education, the poorest segments of society would hardly be able to afford their increasing costs without these associations. In a sense, NGOs assist the declining public sector on which millions of citizens still rely. In my research in Cairo, for example, NGOs' premises often served a community function and could be used free of charge or for a nominal fee as day-care centers; medical clinics; family-planning services; recreational and vocational training classes in sewing, dollmaking, electricalappliance repair; and the like. One association that provides micro-credit loans to single mothers has made it possible for hundreds women to set up vending enterprises in their localities and thereby become functionally self-sufficient. NGOs' headquarters often served a social function, as well, allowing local poor families, mostly women, to gather in public and learn social skills, such as how to talk in public or behave "properly." An estimated 5 million poor people benefit from such associations. ${ }^{75}$ The 3,000 Egyptian CDAs alone serve some 300,000 people by implementing programs in health care, food production, women's projects, family planning, income generation, and child and youth development. ${ }^{76}$

Social development, however, is more than mere survival, relief, and safety net, with total dependence on charity or precarious foreign aid. ${ }^{77}$ In addition, in the current development discourse, social development does not only mean fulfilling basic needs; it also involves achieving social and economic rights and being self-sustaining. This requires, in Anisur Rahman's words, "creating a condition where people can think, use their abilities, and act, that is, to participate." ${ }^{, 78}$ Ideally, an "NGO should work so as to make itself progressively redundant to any group or set of groups with which it has been working intensively." In short, they should mobilize the grass-roots. How well do the Middle Eastern development NGOs meet this goal of mobilization?

Many NGO advocates have complained about the absence of a spirit of participation in the NGOs. Despite a recent tendency to establish professional and advocacy associations, Jordanian NGOs remain largely "charity-driven." ${ }^{, 79}$ Activists hope that they will adopt an "enabling approach." ${ }^{, 80}$ Lebanese NGOs still carry the legacy of war and are active mainly in the fields of relief and emergency; like their Palestinian counterparts, they depend heavily on external humanitarian assistance. ${ }^{81}$ Only recently has there been a clear shift from relief and humanitarian assistance to the developmental and advocacy associations (human rights, women, and democracy). ${ }^{82}$ The Charitable Societies in Palestine have managed to alleviate (in the areas of relief, health, education, and culture) the pressure generated by daily needs. They play a "preventive role at best, by maintaining basic social care, but they do not perform a developmental role in the full sense of the term." ${ }^{83}$ Accordingly, NGOs' overwhelming focus on services at the cost of ignoring productive activities has pushed the Palestinians toward further dependence on the Israeli economy.

Several accounts of NGOs - notably, the likes of the traditional welfare associations in Egypt - point to their largely paternalistic attitudes and structure. ${ }^{84}$ Paternalism is reflected both in local NGOs' top-down internal organization and in their relationship with the beneficiaries. The main decisions in NGOs are made by one or two people, with rare participation of staff, including the extension workers. In turn, staff are 
motivated not by altruistic incentives but by monetary motives. With the dearth of voluntarism, NGO work for status-conscious but low-paid employees appears to be no more than a dull job experience.

Paternalistic NGOs perceive their beneficiaries more as recipients of assistance than as participants in development. For their "favors" and benevolence, NGOs often expect loyalty, support, and service. It is not the place of beneficiaries to question the adequacy and quality of services or the accountability of the NGOs, for this would be interpreted as interfering in NGOs' affairs. It is not the target groups but the NGO leaders and donors who define the needs and priorities of a given NGO. A common problem among Middle Eastern NGOs is project duplication, which results not only from inadequate coordination, but also from ignoring the specific concerns of the beneficiaries. Competition and factionalism among NGOs, and the variations in donors' (often intermediary NGOs) policies prevent coordination of development strategies and add up to the problem of duplication. Indeed, local associations are often subjected to clientelistic relations with the intermediary NGOs, who extend funds to the former.

The professional NGOs, which have grown exponentially in the 1990s, seem to have overcome some of the administrative and attitudinal shortcomings of the more traditional welfare associations. They attempt to practice participatory methods both internally and in relation to their clients, placing the emphasis on professionalism, education, and efficiency. A number of women's, human-rights, and advocacy NGOs reflect this trend today. ${ }^{85}$ However, certain features of professional organizationshierarchy of authority, fixed procedures, rigidity, and the division of labor-tend to diminish the spirit of participation. Rima Hammami has shown in the case of Palestine that local activism and mass organizations before the peace process were mostly mobilizational - that is, the activities were initiated, decided on, and carried out with the involvement of the grass-roots. After the Palestinian National Authority (PNA) was set up, however, the conditions of foreign funding turned these groups into organizations of the professional elite, with particular discourses of efficiency and expertise. This new arrangement tends to create distance between NGOs and the grass-roots. ${ }^{86}$ Thus, what NGO activism means in reality is the activism of NGO leaders, not that of the millions of targeted people. These NGOs serve more their employees than the political beneficiaries.

In addition to the internal problems (paternalism and administrative inadequacy), government surveillance poses a real obstacle to autonomous and healthy operation of NGOs. In general, as with the grass-roots associations, states in the region express a contradictory position toward NGOs: they lend them support as long as the NGOs reduce the burden of social-service provision and poverty alleviation. In the late 1990s, recognition was growing among Middle Eastern states of the contributions made by the voluntary sector in social development, as reflected in new and more favorable NGO laws and the public expression of support for the organizations (as in Egypt, Iran, and Jordan). Yet the governments also fear losing political space, because there is the possibility of NGOs turning oppositional. Professional associations (in Egypt, Jordan, Palestine and Iran) are often drawn into politics, compensating for the absence or inadequacy of political parties. Consequently, governments, while allowing associational life, impose strict legal control by screening initiators; they also check fund-raising, and unilat- 
erally outlaw nonconformist NGOs. This contradictory position is partly a function of the states' economic and political capacities - while economic weakness in a country may unintentionally generate space for people's self-activity, the states' political feebleness usually restrains it. To illustrate, the Iranian government, lacking financial resources to curb population growth in the early 1990 s, mobilized more than 20,000 female volunteers who managed educational work to achieve successful family-planning and primary health-care programs in cities, bringing the growth rate down from a high 3.4 percent in 1987 to 1.4 percent by 1996 . Yet the government fiercely rejected these women's demand to set up an association because it feared independent organization. ${ }^{87}$ In a way, this implies that in practice the state favors certain NGOs (depending on what they do) and is leery of others. For instance, associations that belong to well-connected high officials are treated better than are critical human-rights and women's rights organizations ${ }^{88}$ It is, therefore, crucial not to approach the NGO sector as an homogenous entity. Just as with the concept of "civil society," class and connection intervene to stratify the private voluntary sector.

These handicaps are partially cultural and attitudinal (e.g., the paternalistic approach to development and status orientation) and partly structural. Unlike those of trade unions and cooperatives, the beneficiaries of NGOs are not its members and therefore cannot hold it accountable for inadequacy. The same relationship, in turn, persists between local NGOs and donor agencies; as a result, the NGOs are accountable not to their beneficiaries but to their donors. ${ }^{89}$ Mahmoud Mamdani is perhaps correct in saying that the NGOs do undermine the existing clientelism, yet they simultaneously create a new type..$^{00}$ The question, then, is whether the present NGOs are structurally able to foster grass-roots participation for meaningful development. Perhaps we simply expect too much from NGOs, as Niel Webster, writing on India, has noted. Maybe we attribute "these NGOs with development qualities and abilities that they do not in fact possess." ${ }^{\text {"9l }}$ Whatever our expectations, the fact remains that selfactivity - collective or individual mobilization-remain a crucial factor in poor peoples' elevation to a point at which they can meaningfully manage their own lives. In the Middle East, the existing forms of activism in the communities - or through labor unions, social Islam, and the NGOs - do contribute to the well-being of the underprivileged groups. However, they fall short of activating and directing a great number of people in sustained mobilization for social development. The socio-political characteristics of the Middle East instead tend to generate a particular form of activism-a grass-roots non-movement that, I think, has far-reaching implications for social change. I have called this the "quiet encroachment of the ordinary."

\section{THE QUIET ENCROACHMENT}

The notion of "quiet encroachment" describes the silent, protracted, and pervasive advancement of ordinary people on the propertied and powerful in a quest for survival and improvement of their lives. ${ }^{92}$ They are characterized by quiet, largely atomized, and prolonged mobilization with episodic collective action-open and fleeting struggles without clear leadership, ideology, or structured organization. Although the quiet encroachment is basically a non-movement, it is distinct from survival strategies or "everyday resistance" in that, first, the struggles and gains of the grass-roots are at 
the cost not of fellow poor people or themselves but of the state, the rich, and the general public. In order to light their shelters, the urban poor tap electricity not from their neighbors, but from the municipal power poles; to raise their living standard, they do not prevent their children from attending school so that they can work but, rather, reduce the time they spend at their formal jobs to have more time for their secondary work in the informal sector.

In addition, these struggles should be seen not as necessarily defensive merely in the realm of resistance but as cumulatively encroaching, meaning that the actors tend to expand their space by winning new positions to move on. This kind of quiet activism challenges many fundamental state prerogatives, including the meaning of "order," control of public space, and the meaning of "urban." But the most immediate consequence is the redistribution of social goods in the form of the (unlawful and direct) acquisition of collective consumption (land, shelter, piped water, electricity), public space (street pavement, intersections, street parking places), and opportunities (favorable business conditions, locations, and labels).

Post-Revolution Iran experienced an unprecedented colonization, mostly by the poor, of public and private land, apartments, hotels, street sidewalks, and public utilities. Between 1980 and 1992, despite the government's opposition, the land area of Tehran expanded from 200 square kilometers to 600 square kilometers; well over one hundred mostly informal communities were created in and around greater Tehran. The actors of the massive informal economy extended beyond the typical marginal poor to include the new middle classes, the educated salary-earners whose public-sector positions rapidly declined during the 1980 s. In a more dramatic fashion, millions of rural migrants and the urban poor in Egypt have quietly claimed cemeteries, rooftops, and state and public lands on the outskirts of the city, creating largely autonomous communities. Greater Cairo contains more than 111 'ashwä'iyyāt, or spontaneous settlements housing more than 6 million people who have subdivided agricultural lands and put up shelters unlawfully. Throughout the country, 344 square kilometers of land has come under occupation or illegal construction mainly by low-income groups. Some 84 percent of all housing units from 1970 and 1981 were informally built. To these informal units one should add "vertical encroachments" - the addition of rooms, balconies, and extra space on top of buildings. The capital for construction comes mainly from the jam iyyāt, informal credit systems located in neighborhoods. Many rent the homes unlawfully to other poor families. The prospective tenant provides the "key money," which he borrows from a jamaiyya, to a plot holder, who then uses it to build but rents it to the provider of the key money. The plot holder becomes a homeowner, and the tenant finds a place to live. Both break the law that allows only one year's advance on rent. ${ }^{93}$

Once settled, the poor tend to force the authorities to extend living amenities, or collective consumption, to their neighborhoods by otherwise tapping them illegally. Many poor in Tehran, Cairo, Istanbul, Tunisia, and other cities use illegal running water and electricity by connecting their homes to electricity poles, extending water pipes to their domiciles, or sharing or manipulating utility meters. For instance, illegal use of piped water in the city of Alexandria alone costs, on average, some $\$ 3$ million a year. A cursory look at Cairo-based communities such as Dar Essalaam, Ezbat Sadat, Izbat Kheirullah, Izbat Nasr, and Basaatin show evidence of this widespread phenome- 
non. In late April 1996, the municipality reported that it had cut off 800 illegal electricity lines in the Dar Essalaam and Basaatin communities in a single raid.

This informal and often uncharged use of collective services leaves governments little choice but selectively to integrate the informal settlements, hoping to commit the residents to pay for services they have thus far used illegally. Securing property and community tax is another consideration. Although the poor welcome the extension of provisions, they often cannot afford to pay the bills. Therefore, it is not uncommon to see reinformalization springing up from the fringes of the new formalized communities (as in Tehran's Islamshahr and Cairo's Izbat al-Hajjana).

In the domain of work, "street subsistence workers" quietly take over public thoroughfares to conduct their business on the vast parallel economy. The streets in the commercial districts of Middle Eastern cities are colonized by street vendors who encroach on favorable business opportunities that shopkeepers have created. Cairo reportedly has 600,000 street vendors, and Tehran, until recently, had some 150,000. Informality means not only that the actors generally escape the costs of formality (tax regulation, for instance) but that they also benefit from the theft of imported goods, brands, and intellectual property. With capital of \$6, a Cairene vendor can make up to $\$ 55$ a month. ${ }^{94}$

Thousands of poor (in Cairo, Istanbul, and Tehran, for instance) subsist on tips from parking cars in the streets that they control and organize in such a way as to create maximum parking space. They have turned many streets into virtual parking lots, which they privately control by creating working gangs with elaborate internal organization. Establishing alternative transportation systems is another way to make a living. Izbat Khairullah in Cairo typifies thousands of similar neighborhoods in the region, where vans carry passengers without even registration plates. A newspaper described this community as one in which "no official has ever entered since its establishment" in the early 1980s. ${ }^{95}$ The logic behind these types of encroachment is reflected in the words of a Cairene street vendor, who said, "When dealing with the government, you have to take the proverb, 'What you can win with, play with.,"96

Governments usually send mixed signals about quiet encroachment. On the one hand, they see the people helping themselves by building their own shelters, getting their own services, creating their own jobs. On the other hand, they realize that these activities are carried out largely at the cost of the state, the propertied, and the public. Equally important, the poor tend to out-administer the authorities by establishing a different public order, acting independently and often tarnishing the image of modernity the nation seeks to portray. "We are not against the vendors making a living," says the chief of Cairo's security department, "but not at the expense of Egypt's reputation. They spoil the picture of Cairo, they block the streets, they crowd the pavements." 97

Yet encroachment is tolerated in practice as long as it appears limited. But once it goes too far, governments often react. Post-Revolutionary Iran, for instance, saw many bloody confrontations between the security forces and encroachers. Daily police harassment is a common practice in many Middle Eastern cities. Nevertheless, the frequent offensives against squatters and street vendors often fail to bring a result. The actors either resort to on-the-spot resistance (as in Iran) or, more commonly, resume their activities quietly following each tactical retreat (as in Egypt). For instance, while 
the municipal police drive around to remove street vendors - in which case the vendors suddenly disappear-the vendors normally return to their work once the police are gone. "Everything we are doing is useless," says an Egyptian official. ${ }^{98}$ The Iranian authorities became even more frustrated when "anti-vending squads" failed to clear public spaces. Confronting quiet encroachment is particularly difficult for vulnerable governments. The municipalities, using stick-and-carrot tactics, may indeed manage to demolish communities, drive vendors away from the main streets, or track down unregistered transportation. Nevertheless, they have to yield to the actors' demands by offering alternative solutions. Where removals or demolitions have actually been carried out, the dispossessed have been offered alternative street markets, housing, or regulated taxi service. Only 13 of a total 81 squatter settlements in Cairo (excluding Guiza) have been identified for demolition (for safety reasons); the rest are planned to be upgraded. ${ }^{99}$

Quiet encroachment, therefore, is not a politics of collective demand-making, a politics of protest. Rather, it is a mix of individual and collective direct action. It is accentuated under the socio-political circumstance characterized by authoritarian states, populist ideology, and strong family ties. The authoritarian bureaucratic states make collective demand-making both risky (because of repression) and less than effective (owing to bureaucratic inefficiency); populism tends to obstruct the public sphere and autonomous collectivities, rendering primary loyalties the more functional mechanism of survival and struggle. Yet, in the long run, the encroachment strategy generates a reality on the ground with which states often find no option but to come to terms. In the end, the poor manage to bring about significant changes in their own lives, the urban structure, and social policy. It is precisely this centrality of the agency, of the urban grass-roots, that distinguishes quiet encroachment from any incremental social change that may result from urbanization in general.

Although this kind of activism represents a life-long, sustained, and self-generating advance, it is largely unlawful and constantly involves risk of harassment, insecurity, and repression. As fluid and unstructured forms of activism, encroachment has the advantage of flexibility and versatility, but it falls short of developing legal, financial, organizational, and even moral support. The challenge is to encourage convergence of the mobilizational element of quiet encroachment, the institutional capacity of NGOs, and the consent of the authorities. The Street Food Vendors' Organization (SFVO) in the Egyptian city of Minia displays such a possibility. A number of NGO activists helped 700 vendors organize and gain the support of the local authorities. Once it was set up, the SFVO launched a credit fund, improved hygiene, introduced bulk purchase of foodstuffs, provided group health insurance, helped to ease registration in the state bureaucracy, and eliminated police harassment. This successful experiment has encouraged other cities to take similar initiatives. ${ }^{100}$

Yet the poor's encroachment on the propertied and powerful, the public, and the state is surely not unlimited. The grass-roots might be able to secure many necessary provisions, jobs, and urban services - and these are certainly crucial. But how can they attain schools, public parks, health insurance, and security at home and work, which are linked to the larger structures and processes? One should perhaps begin by recognizing both the potential and the limitations of grass-roots activism, as well as state involvement in redistribution matters at a large scale. 
Early reaction by the urban grass-roots to aspects of ERSA policies during the 1980s included developing coping strategies and mounting urban riots. These strategies, however, seem to have given way to more institutionalized methods of dealing with austerity. The safety nets provided by social Islam and NGOs (coupled with state repression) contributed to this shift in method. With political Islam undermined (institutionalized, co-opted, or curbed) by the end of the 1990s, social Islam, "NGOization," and quiet encroachment, despite their flaws, appear to have become the dominant forms of activism that now contribute to improving some aspects of people's lives in Middle Eastern countries. Although quiet encroachment has a longer history, the spread of Islamism and NGOs gained new momentum in the 1980 s and especially in the 1990s, the period in which neo-liberal economic policies began to be implemented. The growth of these types of activism (along with the new social movements associated with women and human rights) coincides with the relative decline in traditional class-based movements-peasant organizations, cooperative movements, and trade unionism. The transformation of the rural social structure, "de-peasantization," and growing urbanization are eroding the social bases of peasant and cooperative movements. The weakening of economic populism, closely linked to the new economic restructuring, has resulted in a decline of public-sector employment, which constituted the core of the corporatist trade unionism; at the same time, it has led to a growing fragmentation of the workforce, expressed in the expansion of the informal urban economy. State bureaucracy (as a segment of the public sector) continues to remain weighty; however, its employees, unlike workers in industry or services, largely have been unorganized. A large segment of low-paid state employees survive on incomes deriving from second or third jobs in the informal sector.

In the meantime, the increasing informality of economies and expanded urbanization in the Middle East tend to cause a shift in popular needs and demands. The growth of informality means that struggles for wages and conditions, the typical focus of traditional trade unionism, are losing ground in favor of broader concerns for jobs, informal work conditions, and affordable cost of living. Rapid urbanization, however, increases the demand for urban collective consumption-shelter, decent housing, electricity, piped water, transportation, health care, and education. This desire for citizenship, expressed in community membership and developmental rights, is one that traditional trade unionism is unable to address. The task instead falls on community movements that remain feeble in the Middle East. However, the scope of social Islam and NGOs, despite their contributions to social welfare, is also unable to realize fully the goal of social development. By the close of the 1990s, some Middle Eastern governments were cautiously recognizing the activities of some civil-society organizations, especially the social-development NGOs. New NGO laws in Egypt and Palestine, public expression of more positive attitudes in Jordan, and the support given by reformist President Khatami to popular participation in Iran demonstrate some change of attitude. Yet these measures fall short of empowering civil-society organizations from above and encouraging social development from below. It is, therefore, mainly to the strategy of quiet encroachment that the urban grass-roots in the Middle East resort in order to fulfill their growing needs. 
Thus emerges a salient feature of grass-roots activism in the region: it is characterized less by demand-making movements than by direct actions, be they individual, informal, or institutional. Hence, largely because of the inefficient and authoritarian nature of states, people are less inclined to get together to demand housing, than to acquire that housing directly. Similarly, Mosque Associations, instead of mobilizing people to demand welfare from the state, attempt to supply the services directly. Otherwise, people exert collective pressure when their already acquired gains are threatened. In this process, the intervention of advocacy NGOs (such as those for human rights, women, or democracy) to publicize the cause of the grass-roots often contributes significantly to their struggles.

These claim-making acts, collective or individual, have both practical and policy implications. Through direct actions, the grass-roots and their middle-class supporters make themselves heard; they create realities on the ground with which the authorities sooner or later must come to terms. ${ }^{101}$ Joan Nelson's contention that, because the poor are never organized well enough, they fail to exert influence on national policies is true. ${ }^{102}$ Yet the cumulative consequence of poor people's individual direct actions may, in the end, result in some improvements from below and policy changes from above. In short, pressure from below in the experience of the Middle East is highly relevant to social development. Given the gradual retreat of states from their responsibilities in offering social welfare, the poor in the Middle East would have been in a far worse condition had grass-roots actions been totally absent. Yet grass-roots activities do have limitations in terms of their own internal constraints, their capacity to win concessions adequately, and in relations to the constraints directed from the states. It is a mistake to leave the entire task of social development to initiatives from below; a bigger mistake is to give up on the states - in particular, on their crucial role in large-scale distribution. Yet imagining policy change and the concrete improvement of people's lives without their pressure or direct action seems no more than an unwarranted illusion.

\section{NOTES}

Author's note: This article was originally prepared for the United Nations Research Institute for Social Development (UNRISD) in preparation for Social Summit + 5, Geneva, 2000. I thank Mustapha El-Sayyied, Shahra Razavi, Peter Utting, and David Westendorff, as well as the anonymous reviewers of IJMES, for their valuable comments and criticism.

'The average gross national product growth rate for selected Middle Eastern countries during the 1970-79 period were as follows: Egypt, 7.6 percent; Iran, 22.2 percent; Saudi Arabia, 37.2 percent; Turkey, 15.1 percent; Kuwait, 22.6 percent; Syria, 15.4 percent; Iraq, 28.8 percent; Jordan, 19.6 percent; "World Tables 1991," IMF International Financial Statistics Yearbook, 1994, 1996 (Washington, D.C.: IMF Publications, 1996).

${ }^{2}$ See Hazem Biblawi, "Rentier State in the Arab World," in The Arab State, ed. G. Luciani (London: Routledge, 1990).

${ }^{3}$ For a typology of the states in the Middle East, see Alan Richards and John Waterbury, A Political Economy of the Middle East (Boulder, Colo: Westview Press, 1990).

${ }^{4}$ USAID/Cairo/EAS, Report on Economic Conditions in Egypt, 1991-1992 (Cairo: USAID, 1993), 2.

5See John Westley, "Change in Egyptian Economy, 1977-1997," and Jalal Amin, "Major Determinants of Economic Development in Egypt: 1977-1997," both in Cairo Papers in Social Science 21 (1998): 18-49. See also R. Assad and M. Roshdi, Poverty and Poverty Alleviation in Strategies in Egypt (Cairo: Ford Foundation, 1998). For a more recent evaluation of Egypt's development process, see Richard Adams, 
"Evaluating the Process of Development in Egypt, 1980-97," International Journal of Middle East Studies 32 (2000): 255-75.

${ }^{6}$ See Roula Majdalani, "Bridging the Gap Between the Development Agendas and the Needs of the Grassroots: The Experience of Jordanian NGOs" (unpublished ms., Beirut, 1999).

7See Raymond Hinnebusch, "Democratization in the Middle East: The Evidence from the Syrian Case," in Political and Economic Liberalization, ed. Gred Honneman (Boulder, Colo.: Lynn Rienner, 1996).

${ }^{8}$ S. E. Ibrahim, "The Troubled Triangle: Populism, Islam, and Civil Society in the Arab World," International Political Science Review 19 (1998): 373-85.

${ }^{9}$ See A. R. Norton, ed., Civil Society in the Middle East (Leiden: E. J. Brill, 1995).

${ }^{10}$ For conceptual discussion, see Asef Bayat, "From 'Dangerous Classes' to 'Quiet Rebels': Politics of Urban Subaltern in the Global South," International Sociology 15 (2000): 545-69.

${ }^{11}$ Marsha P. Posusney, Labor and the State in Egypt (New York: Columbia University Press, 1997); Unni Wikan, Tomorrow, God Willing (Chicago: University of Chicago Press, 1997); Diane Singerman, Avenues of Participation: Family, Network, and Politics in Cairo's Quarters (Princeton, N.J.: Princeton University Press, 1995); Homa Hoodfar, From Marriage to Market (Berkeley: University of California Press, 1997); Valentine Moghadam, "Women's NGOs in the Middle East and North Africa: Constraints, Opportunities, and Priorities," Organizing Women: Formal and Informal Women's Groups in the Middle East, ed. Dawn Chatty and A. Rabo (Oxford: Berg, 1997); Haleh Afshar, Women in the Middle East: Perceptions, Realities, and Struggles for Liberation (New York: St. Martin's Press, 1993).

${ }^{12} \mathrm{By}$ the end of the $1990 \mathrm{~s}$, more people in the region were living in the cities than in the rural areas, with a large number of them subsisting in poverty. The proportion of the urban population in the Middle Eastern countries in 1996 were as follows: Bahrain, 79 percent; Egypt, 44 percent; Iraq, 73 percent; Jordan, 70 percent; Kuwait, 96 percent; Lebanon, 86 percent; Morocco, 47 percent; Qatar, 91 percent; Saudi Arabia, 80 percent; Syria, 51 percent; Tunisia, 56 percent; Iran, 60 percent; and Turkey, 67 percent.

${ }^{13}$ Richards and Waterbury, Political Economy, 268. For a more thorough analysis, see John Walton and David Seddon, Free Markets and Food Riots (London: Blackwell, 1994).

${ }^{14}$ See Walton and Seddon, Free Markets, 205-14.

${ }^{15}$ See, for instance, Ira Lapidus, Muslim Cities in the Later Middle Ages (Cambridge: Cambridge University Press, 1967), 107.

${ }^{16}$ See Al-Ahali (3 November 1999), 3.

${ }^{17}$ For details, see Asef Bayat, Workers and Revolution in Iran (London: Zed Books, 1987). On the unemployed movement in Iran, see idem, "Workless Revolutionaries: The Unemployed Movement in Revolutionary Iran," International Review of Social History 24 (1997).

${ }^{18}$ See Joel Beinin and Zachary Lockman, Workers on the Nile: Nationalism, Communism, Islam and the Egyptian Working Class, $1882-1954$ (Princeton, N.J.: Princeton University Press, 1988).

${ }^{19}$ Land Center for Human Rights, "Egypt's Labor Conditions During 1998: The Year of Strikes and Protests" (Cairo, 1998).

${ }^{20}$ See Al-Wafd (5 February 1999), 1.

${ }^{21}$ See Walton and Seddon, Free Markets, 210.

${ }^{22}$ Middle East Economic Digest (21 February 1991), special report on Iran.

${ }^{23}$ Posusney, Labor and the State, 5.

${ }^{24}$ See, for instance, Richards and Waterbury, Poltical Economy, 267.

${ }^{25}$ Posusney, Labor and the State, 10.

${ }^{26}$ Cited in Walton and Seddon, Free Markets, 185.

${ }^{27}$ For more detailed figures, see Richards and Waterbury, Political Economy, 140.

${ }^{28}$ For these, I have relied on papers presented at the Workshop on Changing Labour and Restructuring Unionism, First Mediterranean Social and Political Meeting, Florence, 22-26 March 2000. See the papers by Myriam Catusse, "Les Metamorphoses de la Question Syndicale au Marco"; Dara Kawthar, "Labor Market in Lebanon: Evolution, Constraints, and the Role of Unionism"; Fathi Rekik, "Mobilite Sociale et Flexibilite de L'emploi [Tunisia]"; and Francoise Clement, "Changing Labour and Restructuring in Egypt." On Egypt, see also Fatema Farag, "Labour on the Fence," Al-Ahram Weekly (11-17 May 2000), 7. Deena A. Gamile, "The Working Class of Shubra al-Khaima" (unpublished master's thesis, American University in Cairo, 2000).

${ }^{29}$ For Egypt, see various reports, including Fatema Farag, "Labour on the Fence," (11-17 May 2000), 


\section{Asef Bayat}

7. In Iran, the conservative Parliament ratified a law in early 2000 that excludes workshops with fewer than five workers from the provisions of the Labor Law in order to increase productivity and investment.

${ }^{30}$ See Community Development Journal, special issue no. 32 (1997), esp. 101-98 (Keith Popple and Mae Shaw, "Social Movements: Re-Assessing 'Community'").

${ }^{31}$ See Inaz Tawfiq. "Community Participation and Environmental Change: Mobilization in a Cairo Neighborhood" (unpublished master's thesis, American University in Cairo, 1995).

${ }^{32}$ Jailan Halawi, "Mosque Stairs Spark Shubra Riots," Al-Ahram Weekly (18-24 August 1994).

${ }^{33}$ See Shafeeq Ghabra, "Voluntary Associations in Kuwait," Middle East Journal 45 (1991).

${ }^{34}$ See Joost Hiltermann, Behind the Intifada (Princeton, N.J.: Princeton University Press, 1991).

${ }^{35}$ For a good analysis of the CDAs, see Maha Mahfouz, "Community Development in Egypt: The Case of CDAs" (unpublished master's thesis, American University in Cairo, 1992).

${ }^{36}$ Samer El-Karanshawy, "Governance, Local Communities and International Development in Urban Egypt” (unpublished report, Cairo, 1998).

${ }^{37}$ See R. Sadiq Sarvestani, Barrasi-ye Jame-shenakhti-ye Ravabet-e Hamsayegui dar Tehran (Tehran: Tehran University, Institute of Social Studies and Research, 1997).

${ }^{38}$ In 1990, there were 823 such associations, 80 percent of them concentrated in the greater Cairo area: see Hirofumi Tanada, "Survey of Migrant Associations in Cairo Metropolitan Society (Egypt), 1955-1990: Quantitative and Qualitative Data," in Social Science Review 42 (1996).

${ }^{39}$ See Nicholas Hopkins et al., Social Response to Environmental Change and Pollution in Egypt (Cairo: American University in Cairo, Social Research Center, 1998).

${ }^{40}$ Alan Durning, "People Power and Development," Foreign Policy 76 (1989), 71.

${ }^{41}$ This segment draws heavily on my previous article on Egypt: Asef Bayat, "Cairo's Poor: Dilemmas of Survival and Solidarity," Middle East Report 212 (1996).

${ }^{42}$ For a report on Kafr Seif, see Nadia Abdel Taher, "Social Identity and Class in a Cairo Neighborhood," Cairo Papers in Social Science 9 (1986); and for Khak-e Safid, see F. Khosrowkhavar, "Nouvelle banlieue et marginalite: La cite Taleghani a Khak-e Sefid,” in Teheran: Capitale Bicentenaire, ed. C. Adle and B. Hourcade (Tehran: Institut Français de Recherche en Iran, 1992).

${ }^{43}$ See Karanshawy, "Governance," 11.

${ }^{44}$ On this, see a perceptive article by Mustapha El-Sayyid, "Is There a Civil Society in the Arab World?" in Civil Society in the Middle East.

${ }^{45}$ Reported in Manal M. Eid, Informal Economy in Madinat al-Nahda: Resistance and Accommodation among the Urban Poor (unpublished master's thesis, American University in Cairo, 1998), 88

${ }^{46}$ Abdel Moula Ismail, The Liberalization of Egypt's Agriculture Sector and Peasants Movement (Cairo: Land Center for Human Rights, 1998), 136, app. 7.

${ }^{47}$ See John Cross, Informal Politics: Street Vendors and the State in Mexico City (Palo Alto, Calif.: Stanford University Press, 1998).

${ }^{48}$ See, for instance, Gilles Kepel, Muslim Extremism in Egypt (Berkeley: University of California Press, 1986); Nazih Ayubi, Political Islam (London: Routledge, 1991); Salwa Ismail, "The Popular Movement Dimensions of Contemporary Militant Islamism," Comparative Studies in Society and History 42 (2000): 363-93; Paul Lubeck and Bryana Britts, "Muslim Civil Society in Urban Public Spaces," in Urban Studies: Contemporary and Future Perspectives, ed. J. Eade and C. Mele (Oxford: Blackwell, 2001).

${ }^{49}$ See R. Margulies and E. Yildizoglu, "The Resurgence of Islam and Welfare Party in Turkey," in Political Islam, ed. J. Beinin and J. Stork (Berkeley: University of California Press, 1997), 149.

${ }^{50}$ Ugur Akinci, "The Welfare Party's Municipal Track Record: Evaluating Islamist Municipal Activism in Turkey," Middle East Journal 53 (1999): 77-79.

${ }^{51}$ Meriem Verges, "Genesis of a Mobilization: The Young Activists of Algeria's Islamic Salvation Front," in Beinin and Stork, Political Islam, 292-305.

${ }^{52}$ Assaf Kfoury, "Hizb Allah and the Lebanese State," in Beinin and Stork, Political Islam, 136-43.

${ }^{53}$ Roula Majdalani, "Governance and NGOs in Lebanon" (unpublished paper, Beirut, 1999), 13.

${ }^{54}$ The latter figure as given by the current minister of social affairs, Mervat Tallawi, in Aqidati (28 October 1997), 17.

${ }^{55}$ See Amani Qandil, "The Nonprofit Sector in Egypt," in The Nonprofit Sector in the Developing World, ed. H. K. Anheier and L. M. Salamon (Manchester: Manchester University Press, 1998), 145-46.

${ }^{56}$ Manal Badawy, Islamic Associations in Cairo (unpublished master's thesis, American University in 
Cairo, 1999), 110. See also Denis Sullivan, Private Voluntary Associations in Egypt (Bloomington: University Press of Florida, 1994), 65-68.

${ }^{57}$ See Hisham Mubarak, Al-Erhabiyoun Qademoun (Cairo: Dal Al-Mahrousa, 1995).

${ }^{58}$ Cited in Qandil, "Nonprofit Sector in Egypt," 146.

${ }^{59}$ See Saad Eddin Ibrahim, Egyptian Law 32 on Egypt's Private Sector Organizations (Cairo: Ibn Khaldoun Center for Developmental Studies, 1996), Working Paper no. 3; Amani Qandil, "The Role of Islamic PVOs in Social Welfare Policy: The Case of Egypt" (paper presented at the conference on The Role of NGOs in National Development Strategy, Cairo, 28-31 March 1993).

${ }^{60}$ Margulies and Yildizoglu, "Resurgence of Islam," 149.

${ }^{61}$ See Ibrahim, Egyptian Law 32, 34.

${ }^{62}$ Not surprisingly, Western Munira of Imbaba, the stronghold of the Islamists, has been allocated more funding for its development than any other district in north Guiza, to the east of Cairo. Between 1992-93 and 1995-96, some 372.5 million Egyptian pounds were spent on constructing, upgrading, and burnishing this area: Al-Ahram Weekly (24-30 October 1996), 12.

${ }^{63}$ Kfoury, "Hizb Allah," 142.

${ }^{64}$ See Mona Harb el-Kak, "Participation Practices in Beirut's Suburb Municipalities: A Comparison Between Islamic and 'Developmentalist' Approaches" (paper presented at the 4th International Other Connections Conference, Sites of Recovery, Beirut, 25-28 October 1999).

${ }^{65}$ Akinci, "The Welfare Party's Municipal Track Record."

${ }^{66}$ See Amani Qandil, “Taqdim Adaa al-Islamiyya fi-Niqabat al-Mihniyya” (Cairo: CEDEJ/Cairo University, 1993); and Carrie Rosefsky Wickham, "Islamic Mobilization and Political Change: The Islamist Trend in Egypt's Professional Associations," in Beinin and Stork, Political Islam, 120-35.

${ }^{67}$ See Badawy, Islamic Associations in Cairo.

${ }^{68}$ See Gustavo Gutierrez, A Theology of Liberation: History, Politics, and Liberation (New York: Orbis Books, 1988).

${ }^{69}$ This is expressed in many ways by the Islamists. See Youssef al-Karadawi, The Problem of Poverty, and How Can Islam Resolve It (in Arabic) (Beirut: Al-Risalaa, 1985).

${ }^{70}$ See interview with Saiid Hajjarian, a leader of Tehran City Council and an adviser to President Khatami, in Middle East Report 212 (1999). For the data on NGOs, see Qandil, "The Nonprofit Sector in Egypt," 139; Roula Majdalani, "NGOs as Power-Brokers in the Rebuilding of a Fragmented State: The Case of Lebanon" (unpublished paper, Beirut, August 1999), 14; Majdalani, "Bridging the Gap," 2; Khalil Nakhleh, Indigenous Organizations in Palestine (Jerusalem: Arab Thought Forum, 1991); "A Little Neighborly Advice," Cairo Times (2-15 September 1999), 21; Massoumeh Ebtekar, "Women's NGOs and Poverty Alleviation: The Iranian Experience" [in English], Farzaneh 4 (1998), 10. A report by Baquer Namazi, "Iranian NGOs: Situational Analysis" (Tehran, January 2000), provides useful early data. See also Nowrouz (4 Tir 1380/2001), 9.

${ }^{71}$ Both statements were made in the Regional Follow-Up Conference of Arab NGOs, held in Cairo, 17-19 May 1997.

${ }^{72}$ See Daoud Istanbuli, "The Future Role of Palestinian NGOs in an Emerging Palestinian Self-Government," Middle East Working Group Seminar, Jerusalem, 21-22 June 1993, 12.

${ }^{73}$ Among many reports expressing such views, see, for instance, Robert laTowsky, "Financial Profile of Egypt's PVO Sector," report (World Bank, June 1994).

${ }^{74}$ Special report, Cairo Times (2-15 September 1999), 21.

${ }^{75}$ Cited in Ibrahim, Egyptian Law 32.

${ }^{76}$ Federation of Community Development Associations, "Fact Sheet," Cairo, 14 March 1990.

${ }^{77}$ Egyptian NGOs, for instance, made only 3 million Egyptian pounds (less than $\$ 1$ million) in local income in 1991, and the Ministry of Social Affairs could support no more than 35 percent of all PVOs, often unevenly. According to a different study, total state aid to PVOs provided less than 10 percent of sector revenues, and foreign aid only 5 percent. In other words, these PVOs must depend on themselves to survive. Where internal sources are scarce, as in Iraq, Palestine, and Lebanon during the war, dependence on outside funding becomes vital: see Ibrahim, Egyptian Law 32.

${ }^{78}$ Anisur Rahman, People's Self-Development (London: Zed Books, 1993), 67-73.

${ }^{79}$ Majdalani, "Bridging the Gap."

${ }^{80}$ See interview with Curdis Rhodes of Near East Foundation, Jordan, in Economic Perspectives 11 (1993): 7 . 
${ }^{81}$ See Ghassan Sayyah, "Potential Constraints upon NGOs in Lebanon" (paper presented at the workshop Reconstruction, Rehabilitation, and Reconciliation in the Middle East: A View from Civil Society, Ottawa, 21 June 1993).

${ }^{82}$ Majdalani, "NGOs as Power-Brokers," 14.

${ }^{83}$ Nakhleh, Indigenous Organizations, 50.

${ }^{84}$ See Saad Eddin Ibrahim, "Grassroots Participation in Egyptian Development," Cairo Papers in Social Science 19 (1996); Delta Business Service International: Khattab and Associates, "Analysis of Registered Private Voluntary Associations in Cairo and Alexandria," a report (Agency for International Development, Cairo, 21 June 1981); Karanshawy, "Governance, Local Communities"; Fatma Khafagy, "Needs Assessment Survey of NGOs in Egypt," report (African Women's Development and Communications Networks, Cairo, August 1992); Bertrand Laurent and Salma Galal, "PVO Development Project Evaluation Report," report (USAID/Egypt, Cairo, December 1995). On Jordan and Lebanon, see Majdalani, "Governance and NGOs in Lebanon" and "Bridging the Gap," respectively.

${ }^{85}$ See Susan Schaefer Davis, "Advocacy-Oriented Non-Governmental Organization in Egypt: Structure, Activities, Constraints, and Need,” report (USAID/Egypt, Cairo, May 1995).

${ }^{86}$ Rema Hammami, "NGOs: The Professionalization of Politics," Race and Class 37 (1995): 51-63.

${ }^{87}$ Homa Hoodfar, Volunteer Health Workers in Iran as Social Activists? (Paris: WLUML Occasional Paper no. 10, 1998).

${ }^{88}$ Interview with Hasan el-Banna, an official specializing on NGOs in the Ministry of Social Affairs, 1996.

${ }^{89}$ For more detail, see S. Lindberg et al., ed., Globalization, Democratization, and Social Movements in the Third World, research report no. 35 (Lund, Sweden: University of Lund, 1995), 57-58.

${ }^{90}$ See Mahmoud Mamdani's comments in Lindberg et al., Globalization, Democratization, 61.

${ }^{91} \mathrm{~N}$. Webster, "The Role of NGDOs in Indian Rural Development: Some Lessons from West Bengal and Karnataka," European Journal of Development Research 7 (1995), 407-33.

${ }^{92}$ For these theoretical segments, I draw on my Street Politics (New York: Columbia University Press, 1997), chap. 1.

${ }^{93}$ For a more detailed description, see Wikan, Tomorrow, God Willing.

${ }^{94}$ See $R u^{3} y a$ (Cairo), no. 8, 20.

${ }^{95}$ Al-Wafd (18 October 1997), 3.

${ }^{96}$ Reported in Eid, Informal Economy, 105.

${ }^{97}$ Cited in Al-Ahram Weekly (27 November-3 December 1997), 12.

${ }^{98}$ Chief of Cairo's security department referring to the spread of street vendors in Cairo, cited in ibid., 12.

${ }^{99}$ Reported in Al-Wafd (3 March 1998), 3. On Iran, see Bayat, Street Politics. The information on Egypt is based on my research reported in an unpublished paper, "Grassroots Participation in Iran: NGOs or Social Movements" (Cairo: American University in Cairo, 1998).

${ }^{100}$ Reported by Deborah Pugh, "The Street Vendors of Minia," Ford Foundation Report (spring 1994). For more details, see Irene Tinker, Evaluation of the Organization for Development and Support of Street Vendors in the City of Minia (Ford Foundation, August 1993).

${ }^{101}$ Thus, on 1 May 1993, a year after the Imbaba incident in Egypt, President Mubarak authorized "an immediate implementation of a national program in upgrading the most important services and facilities in haphazardly built areas in all governorate." A national five-year-plan campaign was announced covering the period from 1993 to 1998, costing 3.8 billion Egyptian pounds. By 1996, 127 of 527 targeted zones had been "fully upgraded": Al-Ahram Weekly 17-23 (1996), 12.

${ }^{102}$ See Joan Nelson, "The Politics of Pro-Poor Adjustment Policies" (report, World Bank, Country Economics Department, 1988). 